\title{
THE PHYSICAL AND COMPRESSIVE LOAD PROPERTIES OF SUNFLOWER (Helianthus annuus L.) FRUIT
}

\author{
Babić, Lj., Radojčin, M., Pavkov, I. , and Babić, M.
}

Faculty of Agriculture, University of Novi Sad,

Trg Dositeja Obradovica 8, 21000 Novi Sad, Republic of Serbia

Received: August 27, 2012

Accepted: December 10, 2012

\section{SUMMARY}

The physical properties and compressive loading of six domestic sunflower hybrids were studied. The mean values of length, width, thickness, geometric diameter, surface area, porosity, single kernel mass, sphericity, bulk and true density, 1000-kernel weight and coefficient of friction were measured at a single level of moisture content. The results for the sunflower seeds showed that the length, width, thickness and geometric diameter dimensions ranged from 9.31-11.52 $\mathrm{mm}, 4.71-5.92 \mathrm{~mm}, 2.95-4.87 \mathrm{~mm}$ and 5.12-6.31 $\mathrm{mm}$, respectively. The mean sphericity, porosity, static coefficient of friction, bulk and true density ranged from 0.313-0.550, 0.313-0.363, 0.211-0.237, $330.10-449.86$ and 502.74-701.21 $\mathrm{kg} \mathrm{m}^{-3}$, respectively. The objective of this study was to evaluate and compare the behavior of six domestic sunflower hybrids (Perun, Bačvanin, Krajišnik, NS-H-111, Pobednik and Šumadinac hybrids) during compressive loading considering the seed moisture content. The seeds of NS-H-111, Šumadinac, Pobednik and Krajišnik demonstrated low values of bio yield force ranging from $29.3 \mathrm{~N}$ to $45.2 \mathrm{~N}$ when seeds had a low moisture content (between 3.7 and 5.9\% w.b.). The opposite occurred for the Bačvanin and Perun hybrids (60.6 N and $76.2 \mathrm{~N}$, respectively) within the same seed moisture content. For all the hybrids, the machine head displacement (deformation) increased as the seed moisture content increased. The linear model shows a decreasing trend of bio yield modulus for all hybrids as the moisture content of seeds increased.

Key words: compressive loading, horizontal seed orientation, physical properties, sunflower

\section{INTRODUCTION}

The sunflower is the most important oil crop in the Republic of Serbia. According to data from the Statistical Office of the Republic of Serbia (http://

* Corresponding author: Phone: +381 214853 318; Fax: +381 214599 89;

e-mail: ivan@polj.uns.ac.rs 
webrzs.stat.gov.rs), over the last decade, sunflower was grown in Serbia on about 170,000 hectares, with the gross production of 380,000 tons of grain per year. Sunflower farming has a long tradition in the Balkan Peninsula. Sunflower seed is the raw material used for oil production for human consumption, and defatted sunflower meal, when used as a feed for livestock, has advantages over other oilseed crops.

By botanical definition, the sunflower has seeds consisting of two main parts. The hull, or pericarp, is the visible outer component that protects the inner kernel. Information about sunflower seed and kernel physical and mechanical properties are necessary for seeding, harvesting, handling, drying, storage and further processing. Three perpendicular dimensions affect the cleaning process, the kernel surface area influences drying, while sphericity and 1000-kernel weight determine the packaging of the seed. Bulk density affects storage capacity, true density determines vehicle loading, the possibility of aeration and drying depend on porosity, moving on an inclined plane is a function of the static coefficient of friction; compression loading behavior affects the milling process or hullability. All this data, therefore, is necessary for each sunflower hybrid.

Previous studies have described the physical and mechanical properties of sunflower seeds. Jafari et al. (2011) and Santalla and Maschroni (2003) determined sunflower seed properties as a function of moisture content. The behavior of sunflower seeds during compressive loading was reported by Gupta and Das (2000), and the results underscored the differences of seed orientation (horizontal and vertical) at different seed and kernel moisture contents. The authors concluded that compressive rapture force for unhulled seeds and kernels decreases as the moisture content increases, and higher force values were observed for seeds in the vertical orientation. Khodabakhian et al. (2011) conducted similar research with three sunflower hybrids.

In addition to sunflower seeds, studies have reported results for the physical properties of other farm crops (Babić et al., 2001; Babić et al., 2011b; Coskum et al., 2006; Dursun, E. and Dursun, I., 2005; Davis and El-Okene, 2009; Isik and Izli, 2007; Kaleemullah and Gunasekar, 2002; Konak et al., 2002; Karababa, 2006; Kibar and Ozoturk, 2008; Ozturk and Esen, 2008; Saiedirad et al., 2008; Taser et al., 2005; Unal et al., 2008).

The objective of this study is to provide new information about the primary physical properties of the seeds of six domestic sunflower hybrids. The data will provide a comparative evaluation of hybrid seeds behavior in subsequent processing. The tested physical properties are dimensions, geometric mean diameter, surface area, bulk and true density, porosity, sphericity, 1000-seed weight, moisture content and static coefficient of friction. The compression loading behavior of sunflower seeds at different moisture content levels is also evaluated. 


\section{MATERIALS AND METHODS}

\section{Seed Samples}

Six sunflower hybrids from the 2009 harvest season (Krajišnik, Perun, Pobednik, Šumadinac, Bačvanin and NS-H-111) were tested. The samples were obtained from experimental fields of the Institute of Field and Vegetable Crops, Novi Sad. Approximately $5 \mathrm{~kg}$ of hybrid seed of each genotype were collected, placed in plastic bags and delivered to the Faculty of Agriculture. The seeds were manually cleaned to remove all foreign matter. Each sample was divided into two parts: one part was used for the analysis of physical properties at a constant seed moisture content, while the other was divided into four groups that were adjusted to different moisture contents for testing compression loading. The seeds were kept in sealed plastic bags and stored in a refrigerator at $4^{\circ} \mathrm{C}$. Before each compression test, the sample was removed from the refrigerator and allowed to equilibrate to room temperature.

\section{Physical Properties}

The moisture content of seeds from each sunflower hybrid was measured according to the specific regulations for the quality of agricultural crops mandated by the Republic of Serbia (Directive 47/1987). Three replicates were measured for each sample. The samples were oven-dried at $103 \pm 2^{\circ} \mathrm{C}$ for 17 hours and then weighed until the changes between two successive weighings of the sample became negligible (Maghsoudi et al., 2012). This procedure was repeated until the observed change in mass was less than $0.01 \mathrm{~g}$. The samples were then placed in desiccators and allowed to cool to room temperature. The weight of each sample was recorded using a digital balance with an accuracy of $\pm 0.001 \mathrm{~g}$ (Kern, PLJ360-314). The moisture content, Mc (\%), of each sample was expressed on a wet basis (w.b.). Specimens that had been sealed in polyethylene bags to reach different moisture contents were treated similarly.

A calliper with an accuracy of $\pm 0.01 \mathrm{~mm}$ was used to measure three nongraded seed dimensions: length (L), width (W) and thickness (T). The dimensions are reported in millimeters $(\mathrm{mm})$. For these measurements, a sample of 90 kernels was randomly selected from the bulk of each sunflower hybrid; the mean kernel dimension values and standard deviation (SD) were determined and used to establish the kernel size distribution. The geometric mean diameter, $\mathrm{Dg}(\mathrm{mm})$, sphericity, $\Phi(\mathrm{mm} / \mathrm{mm})$, and surface area of a single seed, $\mathrm{S}\left(\mathrm{mm}^{2}\right)$, were calculated from the three principal dimensions according to the following formula (Mohsenin, 1980; Babić and Babić, 2011 a; Babić et al., 2011b):

$$
\begin{aligned}
& D g=(L W T)^{1 / 3} \\
& \Phi=\frac{D g}{L} \\
& S=\pi D g^{2}
\end{aligned}
$$

An electromechanical kernel counter (Numigral, NUM 3, Tripette et Renaud) and a digital balance (KERN, PLJ360-314) were used to measure the one thousand 
non-graded seed weight (g). The test was repeated three times. The mean mass value of a single kernel, $\mathrm{M}$ (g) and its standard deviation (SD) were calculated. The liquid displacement method was used to determine the seed true density, $\rho_{t}\left(\mathrm{~kg} \mathrm{~m}^{-}\right.$ ${ }^{3}$ ). This test was repeated three times, and the mean and standard deviation (SD) of the density were calculated for all sunflower hybrids. The bulk density measurement, $\rho_{\mathrm{b}}\left(\mathrm{kg} \mathrm{m}^{-3}\right)$, was performed by measuring the seed's mass using a digital balance and then measuring the total volume in a graduated cylinder (Republic of Serbia Directive 47/1987). This procedure was repeated three times. The bulk density was calculated as the ratio of the weight of the kernels compared with their volume in the cylinder. The porosity, $p$ (dimensionless), was calculated as the relationship between the bulk density $\left(\rho_{b}\right)$ and the true density $\left(\rho_{t}\right)$ as follows (Mohsenin, 1980):

$$
p=\left(1-\frac{\rho_{b}}{\rho_{t}}\right)
$$

The one thousand seed weight was determined by counting 100 kernels and weighing them on an electronic balance; the result was multiplied by 10 to give the mass of 1000 kernels. The static coefficient of friction was measured for one structural material only, a galvanized metal sheet. An adjustable tilting surface (Gupta and Das, 1997) with a graduated scale was used for these tests. The test was repeated three times for each hybrid. The friction coefficient, $\mu$ (dimensionless), was calculated as the tangent of the measured tilt angle (Babić and Babić, 2011a):

$\mu=\tan \alpha$

The compressive load behavior of sunflower seeds is tested by applying an external force, $\mathrm{F}(\mathrm{N})$, upon the specimen. Biomaterials under compression change in dimension. The result of such an action is strain, an internal reaction of elementary biomaterial particles that is induced by an external force. The stress-strain diagram is a graphical representation of simultaneous values of force and head displacement (stress) recorded during testing. Within the biomaterials, such as sunflower seeds, the stress-strain curve has a point of elastic limit. This point is marked as the bio yield point (Mohsenin, 1980). From an engineering point of view, especially with respect to further sunflower processing, information about the value of the bio yield point force, $\mathrm{F}(\mathrm{N})$, and head displacement or deformation, $\delta_{\mathrm{H}}(\mathrm{mm})$, for different hybrids is interesting and relevant. For this reason, tests of sunflower seed compression in this study were conducted using whole non-grade seeds. Compression tests were applied to seeds in the horizontal orientation. Fifteen replicate tests were conducted for each hybrid, and four different moisture contents of each hybrid were tested. The testing equipment consisted of a loading cell and a computer running the TMS-PRO Texture measurement system (Food Technology Corporation); a trigger load from 0.5 to $500 \mathrm{~N}$ was used. The constant deformation rate was $60 \mathrm{~mm} \mathrm{~min}^{-1}$ before contact with the specimen and $30 \mathrm{~mm} \mathrm{~min}^{-1}$ during compression. The bio yield modulus of elasticity, $\mathrm{Ey}\left(\mathrm{N} \mathrm{mm}^{-1}\right)$, is the ratio of bio yield force 
$\mathrm{F}$ and machine head displacement or deformation mean value, $\delta_{\mathrm{H}}(\mathrm{mm})$, for particular hybrids and moisture contents (Mohsenin, 1980). All statistical analyses were performed using STATISTICA for Windows, version 9.0 (StatSoft, Inc., 2010).

\section{RESULTS AND DISCUSSION}

The frequency distribution of the six seed dimensions in 90-seed samples of Krajišnik, Perun, Pobednik, Šumadinac, Bačvanin and NS-H-111 hybrids is presented in Figures 1 and 2.

The moisture contents on wet basis of the hybrids Krajišnik, Perun and Pobednik were 11.60, 7.01 and 10.60\% w.b., respectively, while the hybrids Šumadinac, Bačvanin and NS-H-111 had moisture contents of 10.90, 11.03 and 6.71 w.b., respectively. In the NS-H-111 hybrid, most of the seeds (86\%) were long (between 9.01 and $10.50 \mathrm{~mm}$ ), followed by Šumadinac (82\%) (between 9.10 and $10.50 \mathrm{~mm}$ ) and Bačvanin (80\%) (between 10.01 and $11.50 \mathrm{~mm}$ ). The result of the Bačvanin length measurement is similar to observations of Santalla and Mascheroni (2003), who reported high oleic seeds as having a moisture content of $8.6 \%$ d.b. With respect to width, 91\% of Šumadinac seeds were between 4.01 and $6.05 \mathrm{~mm}$ wide, $78 \%$ of Bačvanin seeds ranged in width from 5.50 to $7.05 \mathrm{~mm}$, while $77 \%$ of Krajišnik and NS-H-111 seeds had width ranging from 4.01 to $5.50 \mathrm{~mm}$. The results are similar to a width measurement of $4.82 \mathrm{~mm}$ by Voća et al. (2008) and $5.12 \mathrm{~mm}$ reported by Gupta and Das (1977) at 6.2\% d.b. However, Isik and Izli (2007) reported much higher widths $(7.12 \mathrm{~mm}$ at a moisture content of $10.06 \%$ d.b.). In the Krajišnik hybrid, a significant proportion of seed (88\%) was between 2.51 and $4.50 \mathrm{~mm}$ thick, while $73 \%$ of NS-H-111 and Perun seeds ranged in thickness from 2.51 to 3.51 and from 3.01 to $4.01 \mathrm{~mm}$, respectively.

The measured values for length, width and thickness of the 90 tested sunflower seeds from each hybrid fall into a normal distribution (Figure 3) at the 0.95 confidence interval, confirmed by Pearson's chi-squared test.

This finding indicates that the sample size used in this study was sufficiently large and that the measurements were independent of each other. The three axial dimensions for all of the tested hybrids have peaks that are near the mean values, which is an indication that the axial dimensions are relatively uniform. The mean values of the three axial measured dimensions with standard deviation (SD) and other physical properties are presented in Tables 1 and 2 for all of the sunflower hybrids.

The mean geometric diameter, single seed surface area and volume are presented. The geometric mean diameters ranged from $6.31 \pm 0.48 \mathrm{~mm}$ (Pobednik), $6.29 \pm 0.68 \mathrm{~mm}$ (Bačvanin), $7.71 \pm 0.61 \mathrm{~mm}$ (ZP Perun) and $7.18 \pm 0.51 \mathrm{~mm}$ (NS 4015). These results are similar to the results of Isik and Izli (2007) and Jafari, et al. (2011), at a seed moisture content of $6.3 \%$ w.b. The surface area was $125.80 \pm 18.78 \mathrm{~mm}^{2}$ (Pobednik), 125.50 \pm 22.65 (Bačvanin), $83.92 \pm 16.91 \mathrm{~mm}^{2}$ (Šumadinac) and 83.73 \pm 15.59 (NS-H-111). 

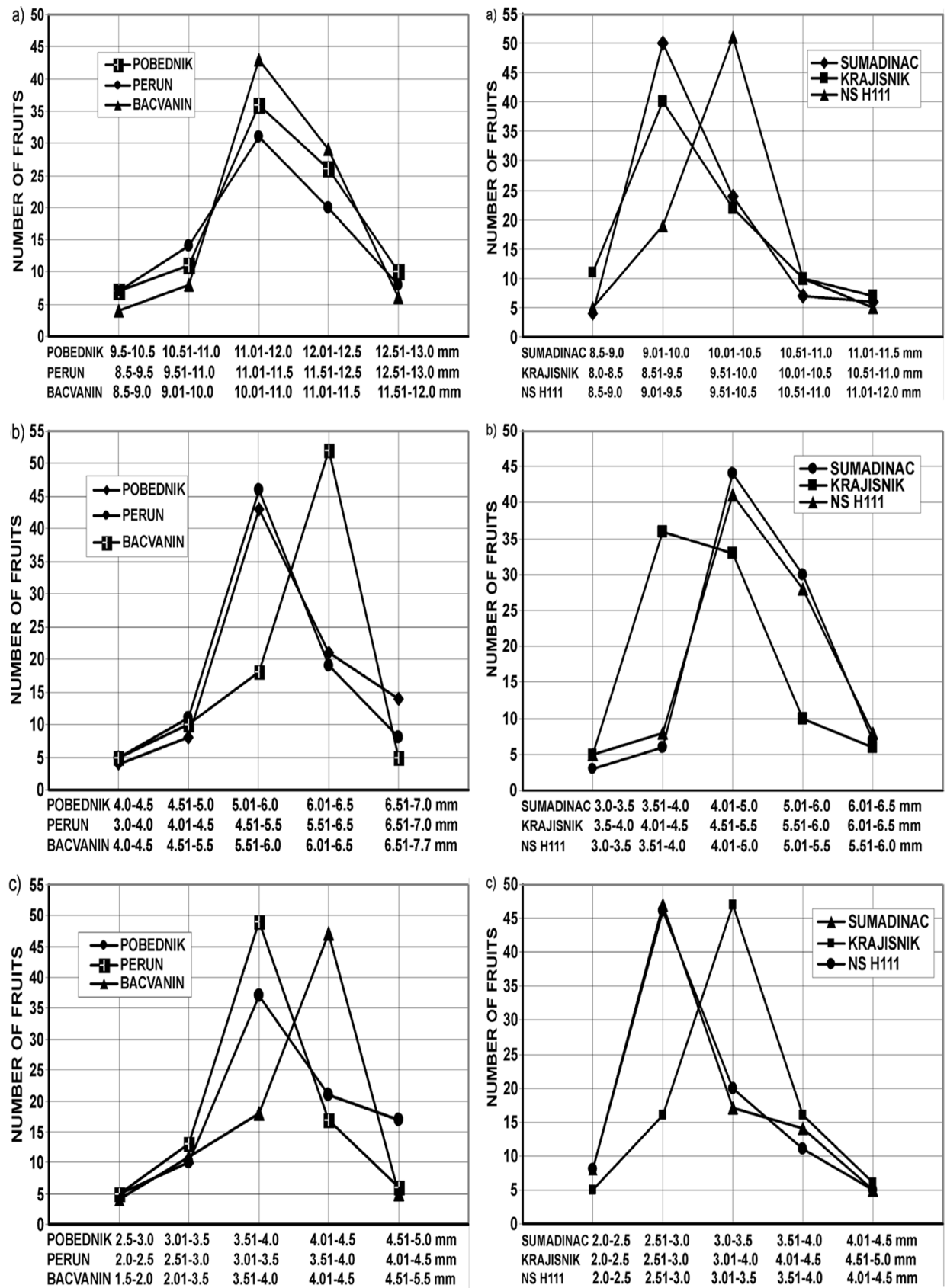

Figure 1: Frequency distribution curves of seed dimensions ( $\mathrm{mm}$ ) for Pobednik, Perun and Bačvanin (a - length; $\boldsymbol{b}$ - width, $\boldsymbol{c}$ - thickness)

Figure 2: Frequency distribution curves of seed dimensions $(\mathrm{mm})$ of Šumadinac, Krajišnik and NS-H-111 (a - length; $\boldsymbol{b}$ - width, $\boldsymbol{c}$ - thickness) 


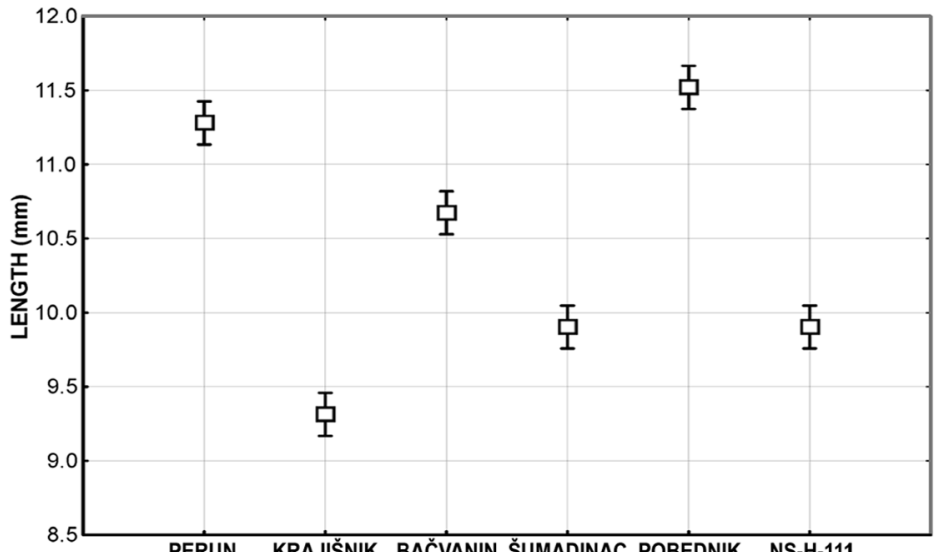

PERUN KRAJIŠNIK BAČVANIN ŠUMADINAC POBEDNIK NS-H-111 HYBRID
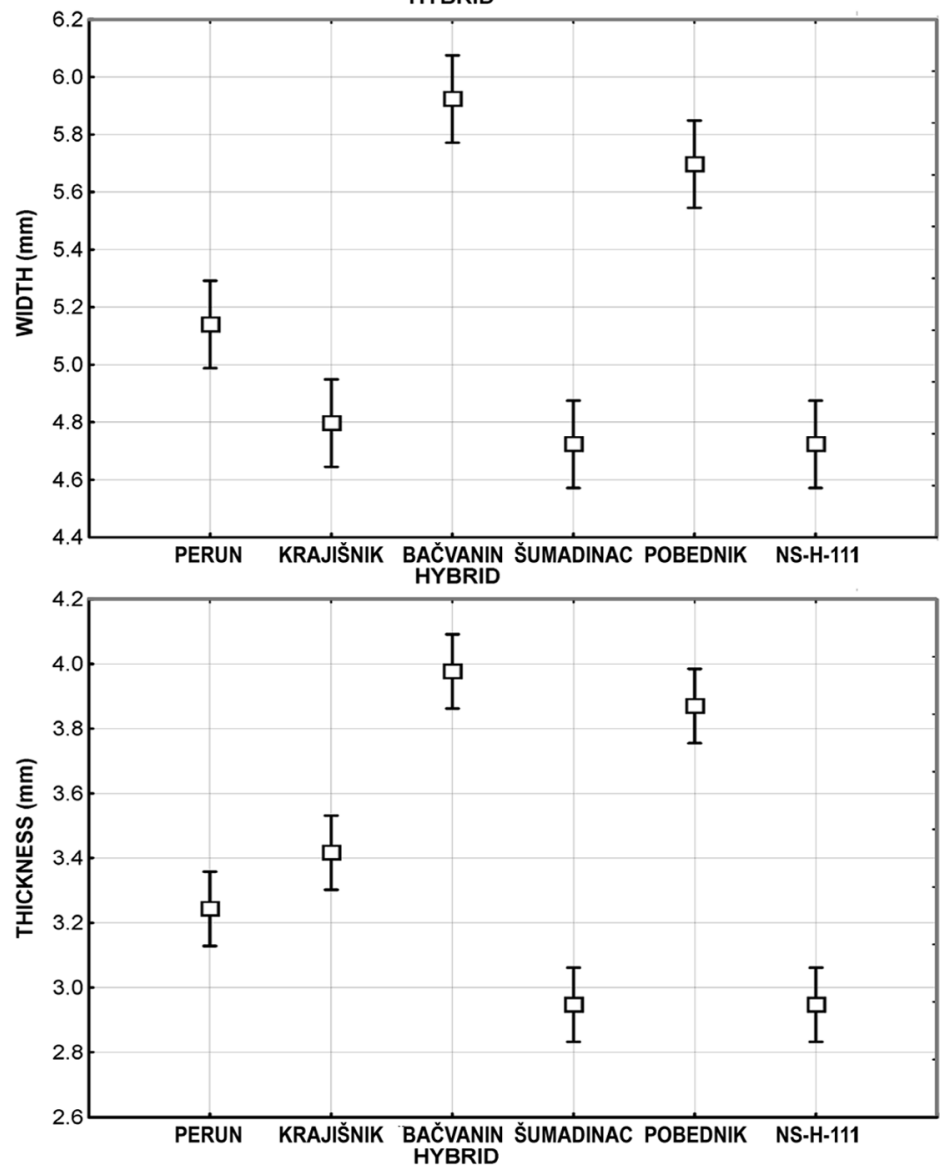

Figure 3: Mean values of length, width and thickness of non-graded seeds assessed by Pearson's chi-squared test (95\% confidence interval) 
Table 1: The mean value and standard deviation \pm SD of the sunflower hybrids' physical properties analysed by the Tukey HSD test at a probability level of 95\%

\begin{tabular}{|c|c|c|c|}
\hline Physical property & Šumadinc & Krajišnik & Bačvanin \\
\hline Length $(\mathrm{mm}) \mathrm{L}$ & $9.8 \pm 0.62 a$ & $9.31 \pm 0.62 b$ & $10.67 \pm 0.68 c$ \\
\hline Width $(\mathrm{mm}) \mathrm{W}$ & $4.72 \pm 0.76 a$ & $4.80 \pm 0.74 a$ & $5.92 \pm 0.61 b$ \\
\hline Thickness (mm) T & $2.95 \pm 0.49 a$ & $3.42 \pm 0.67 b$ & $3.98 \pm 0.62 c$ \\
\hline Geom. mean dia. $(\mathrm{mm}) \mathrm{Dg}$ & $5.14 \pm 0.52 a$ & $5.32 \pm 0.59 a$ & $6.29 \pm 0.68 b$ \\
\hline Surface area $\left(\mathrm{mm}^{2}\right)$ & $83.92 \pm 16.91$ & $102.3 \pm 18.741$ & $125.50 \pm 22.65$ \\
\hline Single kernel mass (g) & $0.0602 \pm 0.0143$ & $0.051 \pm 0.04$ & $0.058 \pm 0.07$ \\
\hline Kernel volume $\left(\mathrm{mm}^{3}\right)$ & $73.37 \pm 21.95 a$ & $81.52 \pm 25.68 a$ & $133.89 \pm 33.14 b$ \\
\hline Sphericity $\left(\mathrm{mm} \mathrm{mm}^{-1}\right)$ & $0.52 \pm 0.050 a$ & $0.57 \pm 0.060 \mathrm{~b}$ & $0.59 \pm 0.051 b$ \\
\hline Porosity (-) & $0.353 \pm 0.14 a$ & $0.313 \pm 0.14 b$ & $0.342 \pm 0.18 a$ \\
\hline Static coeff. of friction (-) & $0.211 \pm 0.074 a$ & $0.215 \pm 0.072 a$ & $0.213 \pm 0.065 a$ \\
\hline Moisture content (\%) w.b. & $10.9 \pm 0.27$ & $11.60 \pm 0.13$ & $11.03 \pm 0.76$ \\
\hline Bulk density $\left(\mathrm{kg} \mathrm{m}^{-3}\right)$ & $419.37 \pm 22.75 a$ & $398.90 \pm 12.72 a$ & $330.10 \pm 10.41 b$ \\
\hline True density $\left(\mathrm{kg} \mathrm{m}^{-3}\right)$ & $649.48 \pm 27.32 a$ & $581.13 \pm 21.11 \mathrm{~b}$ & $502.74 \pm 13.71 \mathrm{C}$ \\
\hline Weight of 1000 kernels (g) & $60.24 \pm 9.78 a$ & $51.48 \pm 10.69 a$ & $58.02 \pm 9.26 a$ \\
\hline L/W & $2.14 \pm 0.35 a$ & $1.98 \pm 0.30 \mathrm{ab}$ & $1.81 \pm 0.211$ \\
\hline $\mathrm{L} / \mathrm{T}$ & $3.45 \pm 0.64 a$ & $2.83 \pm 0.61 b$ & $2.79 \pm 0.70 b$ \\
\hline L/Dg & $1.94 \pm 0.19 a$ & $1.76 \pm 0.18 b$ & $1.71 \pm 0.18 b$ \\
\hline
\end{tabular}

Average \pm Standard deviation. Different letters within the same column represent the statistical difference (HSD, $\mathrm{P}<0.05)$

Table 2: The mean value and standard deviation \pm SD of the sunflower hybrids' physical properties analysed by the Tukey HSD test at a probability level of $95 \%$

\begin{tabular}{lccc}
\hline Physical property & Perun & Pobednik & NS-H-111 \\
\hline Length $(\mathrm{mm}) \mathrm{L}$ & $11.28 \pm 0.87 \mathrm{a}$ & $11.52 \pm 0.79 \mathrm{a}$ & $9.89 \pm 0.62 \mathrm{~b}$ \\
Width $(\mathrm{mm}) \mathrm{W}$ & $5.14 \pm 0.92 \mathrm{a}$ & $5.70 \pm 0.64 \mathrm{~b}$ & $4.76 \pm 0.76 \mathrm{c}$ \\
Thickness $(\mathrm{mm}) \mathrm{T}$ & $3.24 \pm 0.43 \mathrm{a}$ & $4.87 \pm 0.55 \mathrm{~b}$ & $2.90 \pm 0.43 \mathrm{c}$ \\
Geom. mean dia. $(\mathrm{mm}) \mathrm{Dg}$ & $5.71 \pm 0.61 \mathrm{a}$ & $6.31 \pm 0.48 \mathrm{~b}$ & $5.12 \pm 0.59 \mathrm{c}$ \\
Surface area $\left(\mathrm{mm}^{2}\right)$ & $103.25 \pm 22.07 \mathrm{a}$ & $125.80 \pm 18.87 \mathrm{~b}$ & $83.73 \pm 15.59 \mathrm{c}$ \\
Single kernel mass $(\mathrm{g})$ & $0.059 \pm 0.071 \mathrm{a}$ & $0.079 \pm 0.092 \mathrm{~b}$ & $0.0591 \pm 0.042 \mathrm{a}$ \\
Kernel volume $\left(\mathrm{mm}^{3}\right)$ & $100.51 \pm 32.21 \mathrm{a}$ & $133.82 \pm 29.68 \mathrm{~b}$ & $73.33 \pm 21.12 \mathrm{c}$ \\
Sphericity $\left(\mathrm{mm} \mathrm{mm}^{-1}\right)$ & $0.51 \pm 0.062 \mathrm{a}$ & $0.55 \pm 0.063 \mathrm{~b}$ & $0.52 \pm 0.056 \mathrm{ab}$ \\
Porosity $(-)$ & $0.341 \pm 0.12 \mathrm{a}$ & $0.363 \pm 0.09 \mathrm{~b}$ & $0.340 \pm 0.12 \mathrm{a}$ \\
Static coeff. of friction $(-)$ & $0.236 \pm 0.072 \mathrm{a}$ & $0.237 \pm 0.068 \mathrm{a}$ & $0.225 \pm 0.069 \mathrm{a}$ \\
Moist. content $(\%) \mathrm{W} . \mathrm{b}$. & $7.01 \pm 0.46$ & $10.6 \pm 1.28$ & $6.71 \pm 1.28$ \\
Bulk density $\left(\mathrm{kg} \mathrm{m}^{-3}\right)$ & $424.62 \pm 18.29 \mathrm{a}$ & $449.86 \pm 26.03 \mathrm{~b}$ & $435.35 \pm 19.59 \mathrm{ab}$ \\
True density $\left(\mathrm{kg} \mathrm{m}^{-3}\right)$ & $642.41 \pm 21.172 \mathrm{a}$ & $701.21 \pm 31.42 \mathrm{~b}$ & $663.89 \pm 26.73 \mathrm{a}$ \\
Weight of $\left.1000 \mathrm{kernels}^{-} \mathrm{g}\right)$ & $59.21 \pm 2.39 \mathrm{a}$ & $79.32 \pm 5.68 \mathrm{~b}$ & $59.16 \pm 40.11 \mathrm{a}$ \\
L/W & $2.27 \pm 0.52 \mathrm{a}$ & $2.04 \pm 0.26 \mathrm{a}$ & $2.14 \pm 0.35 \mathrm{a}$ \\
L/T & $3.53 \pm 0.52 \mathrm{a}$ & $3.03 \pm 1.83 \mathrm{~b}$ & $3.45 \pm 0.64 \mathrm{a}$ \\
L/Dg & $1.99 \pm 0.19 \mathrm{a}$ & $1.83 \pm 0.15 \mathrm{~b}$ & $1.94 \pm 0.19 \mathrm{ab}$ \\
\hline
\end{tabular}

Average \pm Standard deviation. Different letters within the same column represent the statistical difference (HSD, $\mathrm{P}<0.05)$ 
The results of Oraki et al. (2011) for these seed properties at the moisture content of $10.00 \%$ w.b. are similar to the measurement results for Šumadinac and NS$\mathrm{H}-111$. The highest seed volume was obtained for Bačvanin $\left(133.89 \pm 33.14 \mathrm{~mm}^{3}\right)$, followed by Pobednik $\left(133.82 \pm 29.68 \mathrm{~mm}^{3}\right)$. The lowest volume value was observed for NS-H-111 seeds $\left(73.33 \pm 25.12 \mathrm{~mm}^{3}\right)$.

The single seed mass and 1000-seed weight values and SD were highest for the Šmadinac hybrid, $0.0602 \pm 0.0143 \mathrm{~g}$ and $60.24 \pm 9.78 \mathrm{~g}$, respectively, while the lowest values of $0.051 \pm 51.48 \mathrm{~g}$ and $51.69 \pm 10.69 \mathrm{~g}$, respectively, were measured in Krajišnik. These results correspond to those of Isik and Izli (2007). However, Seifis's (2010) result for 1000-seed weight was significantly higher (80.3 to $96.8 \mathrm{~g}$ ) at a moisture content range of $4-22 \%$ w.b. The value of sphericity was the highest for the hybrid Bačvanin $(0.59 \pm 0.05)$, followed by that for the Krajišnik $(0.57 \pm 0.06)$ and Pobednik $(0.55 \pm 0.06)$ hybrids, which is in agreement with the results of Gupta and Das (1997) and Voća et al. (2008). The lowest value of sphericity was measured in Šumadinac seeds $(0.243 \pm 0.046)$ as a consequence of a small thickness value. The porosity of bulk sunflower seed was $0.313 \pm 0.14$ (Krajišnik), 0.353 \pm 0.14 (Šumadinac) and 0.363 \pm 0.09 (Pobednik). These results are in agreement with Voća et al. (2008) and Gupta and Das (1997) at a seed moisture contents of approximately $10.00 \%$ w.b.

The mean value of bulk density was the lowest for Bačvanin $(330.90 \pm 12.72 \mathrm{~kg}$ $\mathrm{m}^{-3}$ ). The highest value, $449.86 \pm 26.03 \mathrm{~kg} \mathrm{~m}^{-3}$, occurred in the Pobednik hybrid, whose single seed mass has the highest value compared with the other hybrids. The measured values are lower compared with the results of Khodobakhshian et al. (2010) but are in agreement with Voća et al. (2008) and Gupta and Das (1997). The lowest values of bulk density $\left(331.10 \pm 10.41 \mathrm{~kg} \mathrm{~m}^{-3}\right)$ and true density $\left(502.74 \pm 13.71 \mathrm{~kg} \mathrm{~m}^{-3}\right)$ were measured in Bačvanin seeds. The Pobednik true density mean value was $701.21 \pm 31.42 \mathrm{~kg} \mathrm{~m}^{-3}$, followed by NS-H-111 $\left(663.89 \pm \mathrm{kg} \mathrm{m}^{-3}\right)$ and Šumadinac $\left(649.48 \pm 27.32 \mathrm{~kg} \mathrm{~m}^{-3}\right)$. The highest static coefficient of friction value (using a stainless steel sheet as a structural surface) was observed with Pobednik (0.237 \pm 0.068$)$, followed by the seeds of Perun $(0.236 \pm 0.072)$ and NS-H$111(0.225 \pm 0.069)$. The other hybrids tested had similar values of $0.211 \pm 0.074$ (Šumadinac) and $0.215 \pm 0.072$ (Krajišnik). These results correspond with the reports of Mohsenin (1980) and Seifi (2010) for the same structural surface area and seed moisture content values. All of the physical properties in Tables 1 and 2 were measured at single values of seed moisture, Mc (\% w.b.), presented in the tables.

Different parameters were derived from the slow compression loading studies of the six tested sunflower hybrids at various moisture contents. The maximum value on the non-linear part of the curve is marked as the bio yield point, followed by the rapture point. Figure 4 presents the typical compression loading behavior of three hybrids at a single value of seed moisture content obtained during the tests. 


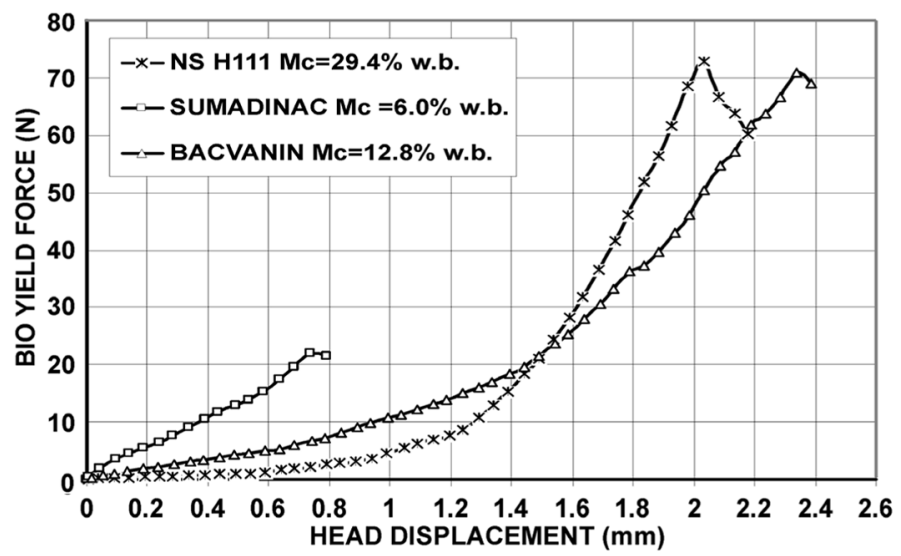

Figure 4: Force and head displacement (deformation) curves of Šumadinac, Bačvanin and NS-H-111
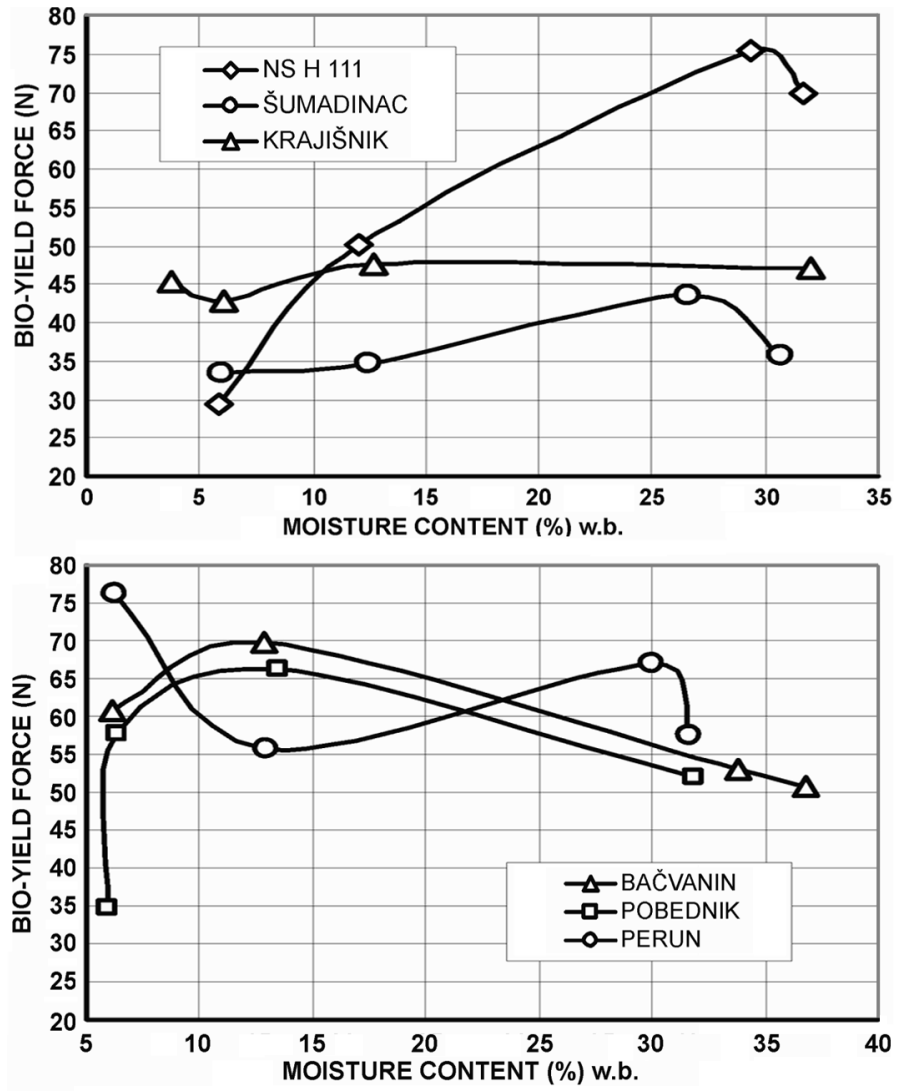

Figure 5: Bio yield force versus seed moisture content during the compression test of sunflower hybrids 
The mechanical behavior of the sunflower seed under uniaxial loading is a function of its moisture content and genotype. The presence of a larger amount of water molecules in the hull and kernel increases the volume. The water molecules enter the polymeric chain and force it to rearrange, which affects the compressive behavior of the whole seed. The bio yield point force-moisture content curves for all sunflower hybrids are shown in Figure 5.

The test data of bio yield forces as a function of moisture content indicate that the hybrid NS-H-111 displayed a high force value $(69.9 \mathrm{~N})$ at $31.7 \%$ w.b. of seed moisture content. A similar observation was reported by Jafari et al. (2011), whose bio yield force had a higher value when the seed moisture content increased. The compression curve of NS-H-111 is expressed by the polynomial equation:

$$
\mathrm{F}=-0.1024 \mathrm{Mc}^{2}+5.5118 \mathrm{Mc}-0.2372 \quad \mathrm{R}^{2}=0.9934
$$

The peak, which occurs for NS-H-111 and Perun at the higher moisture content of seed, is the result of kernel cotyledon separation because of water soaking. The relationship between bio yield force and the moisture of seed for the other hybrids is expressed by the following equations:

For Krajišnik F =-0.0113 $\mathrm{Mc}^{2}+0.5194 \mathrm{Mc}+42.126 \quad \mathrm{R}^{2}=0.5448$

For Šumadinac $\mathrm{F}=-0.0066 \mathrm{Mc}^{3}+0.3172 \mathrm{Mc}^{2}-3.9179 \mathrm{Mc}+47.016 \mathrm{R}^{2}=1$

The hybrids Bačvanin and Pobednik attain maximum bio yield forces of $69.7 \mathrm{~N}$ and $66.2 \mathrm{~N}$ with moisture contents of 12.8 and $13.5 \%$ w.b., respectively. Further increasing of the seed moisture content causes a decreasing of bio yield forces. A similar trend was observed by Gupta and Das (2000) during the sunflower seed compression test with the horizontal orientation of the seed. The hybrid Perun shows quite a different behavior. The minimum value of bio yield force of $55.6 \mathrm{~N}$ is observed at $12.9 \%$ w.b. of seed moisture, while the maximum force value of $76.2 \mathrm{~N}$ is recorded at a moisture content of $6.2 \%$ w.b. The measured bio yield forces for all the tested hybrids are lower than those recorded by Khodabakhshian et al. (2011). The relationships between bio yield forces and seed moisture contents are:

For Bačvanin $\mathrm{F}=-0.4561 \mathrm{Mc}+68.742 \quad \mathrm{R}^{2}=0.6534$

For Perun $\mathrm{F}=0.1138 \mathrm{Mc}^{2}-4.7587 \mathrm{Mc}+100.22 \quad \mathrm{R}^{2}=0.66$

Gupta and Das (2000) emphasized that the hull is fragile at lower seed moisture contents; therefore, the initiation of its rapture occurs at lower bio yield force values. The results of this study confirm previous findings for NS-H-111, Šumadinac, Krajišnik and Bačvanin, while Perun and Pobednik seeds exhibited different behavior. This different behavior probably results from the histological architecture of the hull or pericarp (the outer shell of the kernel). The two main components of the hull are the sclerenchyma and parenchyma (Hernandez and Belles, 2007), which occupy $20-27 \%$ d.b. of the entire seed. The scerenchyma consists of lignin (20-25\% d.b.). The pericarp is arranged in several layers that differ in their cell structure and mechanical properties. The outside of the epidermis is composed of cells that are rectangular in shape. The hypodermis has cells with thin 
walls. Sclerenchyma cells are polygonal and insert with parenchyma cells at regular spaced intervals in the shape of rays. Such a biochemical construction differs significantly by sunflower genotype, which is the only explanation of the different behavior of Perun and Pobednik during compressive loading.

Deformation (machine head displacement) of the sunflower seeds at bio yield force is plotted in Figure 6.
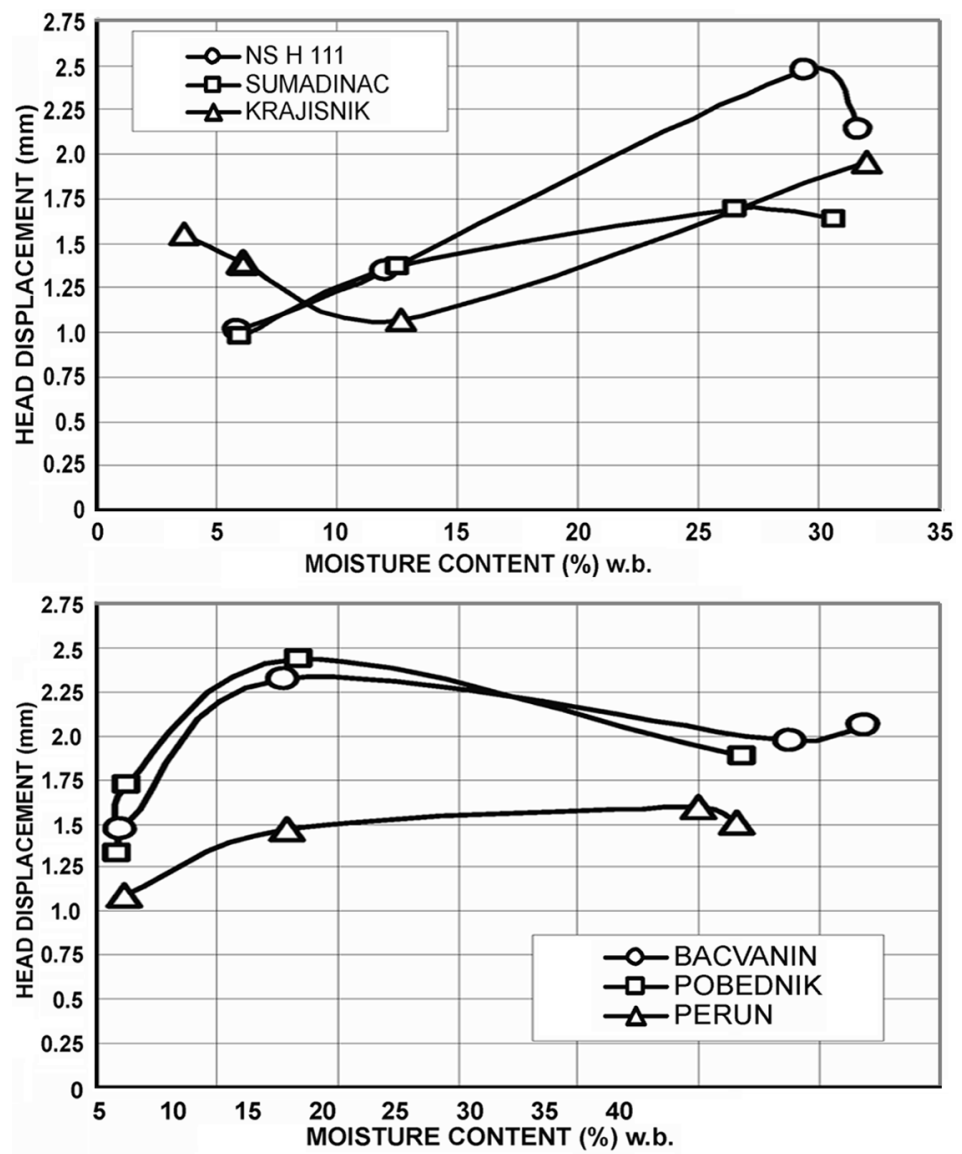

Figure 6: Relationship between head displacement at the bio yield point and moisture content for all sunflower hybrids

The values of head displacement were in a narrow range for all hybrids at lower moisture content because the hull and the kernel are both brittle. The hybrids NSH-111, Šumadinac, Krajišnik and Perun exhibited an increasing trend of deformation as the seed moisture content increased. The same observation was previously reported by Gupta and Das (2000) and Jafari et al. (2011). The results of this study statistically confirm the linear relationship among head displacement, deformation and seed moisture content. 
The equations for these relationships are:

For NS-H-111 $\delta_{\mathrm{H}}=0.15 \mathrm{Mc}+0.7327$

$$
\begin{aligned}
& \mathrm{R}^{2}=0.9257 \\
& \mathrm{R}^{2}=0.8765 \\
& \mathrm{R}^{2}=0.4031 \\
& \mathrm{R}^{2}=0.6887
\end{aligned}
$$

For Perun $\delta_{\mathrm{H}}=0.0145 \mathrm{Mc}+1.1233$

Bavčanin and Pobednik exhibited a maximum deformation of $2.32 \mathrm{~mm}$ at a seed moisture content of $12.8 \%$ w.b. and $2.43 \mathrm{~mm}$ at a seed moisture content of $13.5 \%$ w.b., respectively. As the seed moisture content of these hybrids increased, the maximum deformation values decreased according to the following equations:

For Bačvanin $\delta_{\mathrm{H}}=-0.0002 \mathrm{Mc}^{3}-0.0175 \mathrm{Mc}^{2}-0.3935 \mathrm{Mc}-0.3329 \mathrm{R}^{2}=1$

For Pobednik $\delta_{\mathrm{H}}=-0.0061 \mathrm{Mc}^{2}+0.2457 \mathrm{Mc}+0.246$

$$
\mathrm{R}^{2}=0.9515
$$

The work of bio yield forces at different seed moisture contents is presented in Figure 7.
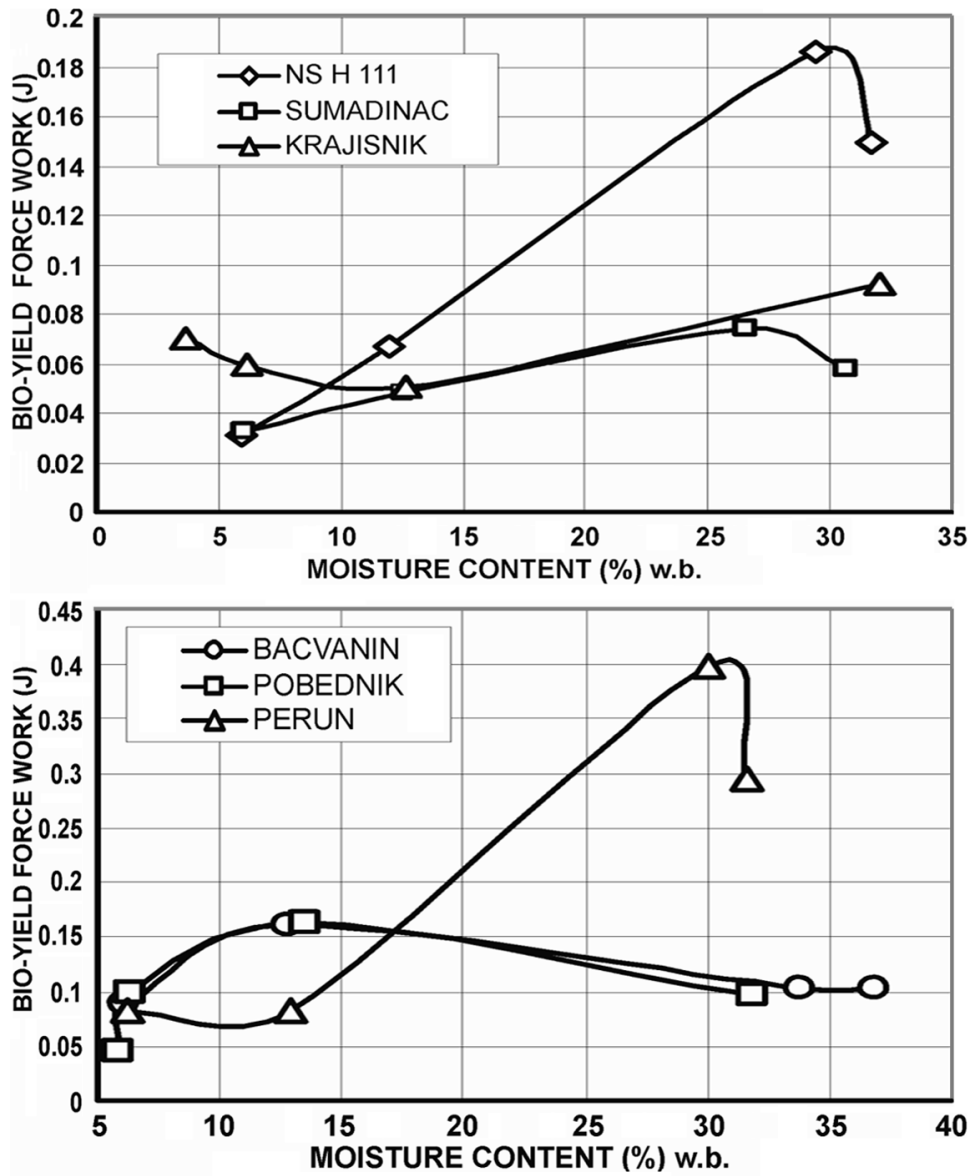

Figure 7: The work of bio yield forces for tested hybrids 
The increasing work values occur when the seed moisture content increases (similar to increasing trends for deformation) for the hybrids NS-H-111, Šumadinac, Krajišnik and Perun. These results are in agreement with a report by Gupta and Das (2000) on the absorbed energy of sunflower seed and kernel for moisture contents ranging from 4.21 to $10.65 \%$ d.b. Bačvanin and Pobednik had a decreasing bio yield work tendency as a function of the seed moisture content. The distinct peak in the graphs for NS-H-111 and Perun is the result of high values of deformation because of seed softening.

Šumadinac, Krajišnik and Bačvanin demonstrated a decreasing trend of bio yield modulus as the seed moisture content increased. These results statistically confirm the linear relationship between the bio yield modulus of elasticity and the seed moisture content (Figure 8).
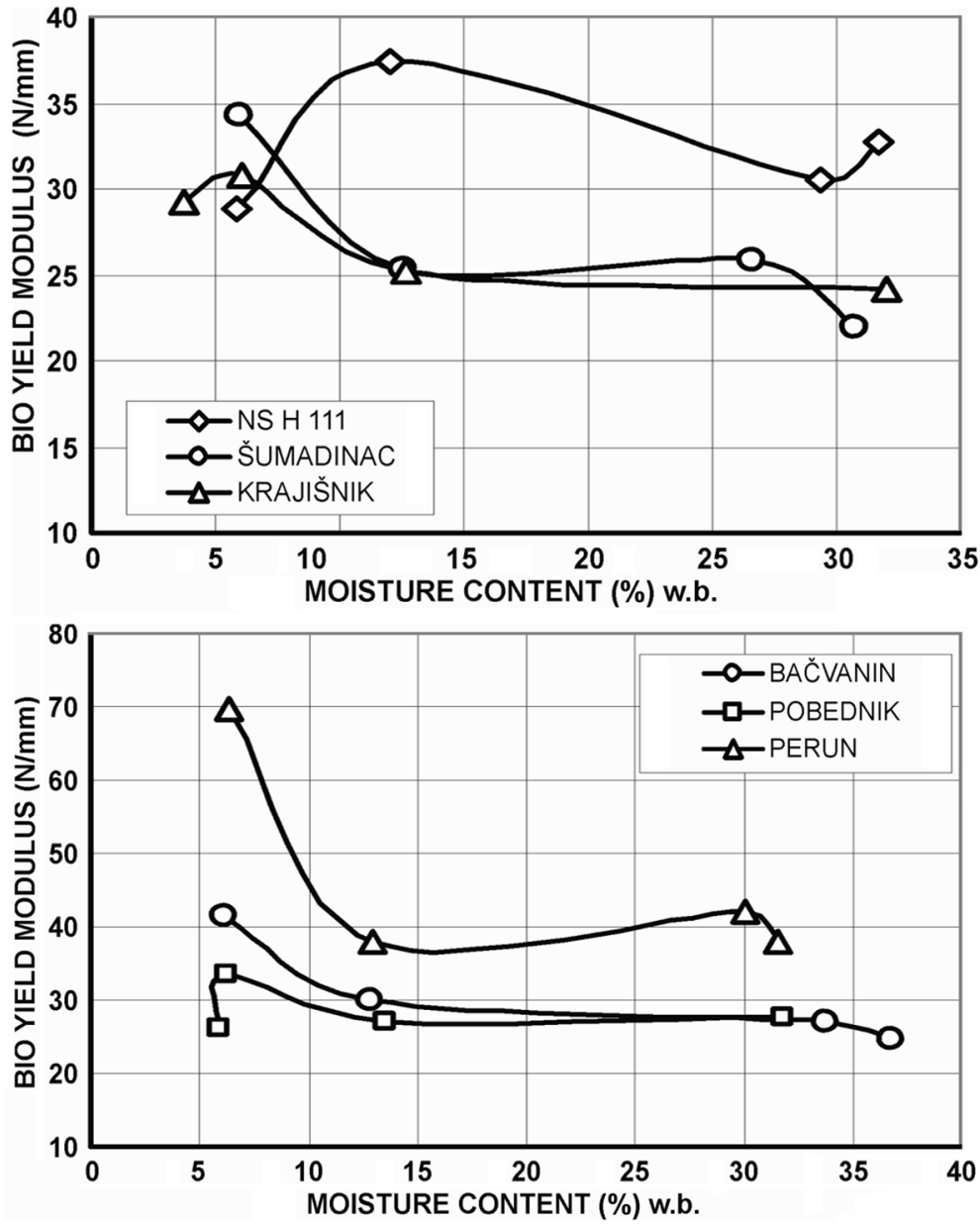

Figure 8: Bio yield modulus of sunflower hybrids versus seed moisture content 
The equations that express these relationships are:

$$
\begin{array}{ll}
\text { For Šumadinac Ey }=-0.375 \mathrm{Mc}+33.936 & \mathrm{R}^{2}=0.6945 \\
\text { For Krajišnik } \mathrm{Ey}=-0.2044 \mathrm{Mc}+30.112 & \mathrm{R}^{2}=0.6953 \\
\text { For Bačvanin } \mathrm{Ey}=-0.4282 \mathrm{Mc}+40.316 & \mathrm{R}^{2}=0.7732
\end{array}
$$

There were no distinctions between Bačvanin and Pobednik through the compressive test loading. For example, for Bačvanin and Pobednik the bio yield forces were $69.73 \mathrm{~N}$ (12.8\% moisture) and $66.18 \mathrm{~N}$ (13.5\% w.b. seed moisture), respectively; and consequently, the values for the bio yield work and modulus of elasticity were similar. The seeds of Perun and NS-H-111 had different genetic origins than the other hybrids, which resulted in different seed behavior during compression loading. Perun had a low scope of seed deformation, ranging from $1.09 \mathrm{~mm}$ to 1.51 $\mathrm{mm}$ (seed moisture in range 6.2-31.6\% w.b.), and measured bio yield forces (between $55.6 \mathrm{~N}$ and $76.2 \mathrm{~N}$ ). The maximum bio yield force was $76.2 \mathrm{~N}$ at the lowest moisture content. These data demonstrate that the hull firmness of Perun is outstanding across the entire range of moisture content. In contrast, the NS-H-111 hybrid had a larger scope of deformation, from $0.988 \mathrm{~mm}$ (5.9\% w.b. of seed moisture) to $2.46 \mathrm{~mm}$ ( $29.4 \%$ w.b. moisture content of the seed), which influenced not only the bio yield work but also the higher values of bio yield modulus. The NS-H111 and Perun hybrids differed significantly in the bio yield modulus values from the other hybrids. According to Table 2, the three perpendicular dimensions of Perun are larger $(\mathrm{L}=11.28 \mathrm{~mm}, \mathrm{~W}=5.14 \mathrm{~mm}$ and $\mathrm{T}=3.24 \mathrm{~mm})$ than those of NS-H$111(\mathrm{~L}=9.89 \mathrm{~mm}, \mathrm{~W}=4.76 \mathrm{~mm}$ and $\mathrm{T}=2.90 \mathrm{~mm})$. However, the bulk and true densities of NS-H-111 (435.35 $\mathrm{kg} \mathrm{m}^{-3}$ and $663.89 \mathrm{~kg} \mathrm{~m}^{-3}$, respectively) are larger than those of Perun (424.62 $\mathrm{kg} \mathrm{m}^{-3}$ and $642.41 \mathrm{~kg} \mathrm{~m}^{-3}$, respectively). The kernel of the Perun hybrid does not fill the interior of the hull, as compared with the NS-H-111 hybrid. The seed of NS-H-111 fills the inner cavity much better than that of the Perun hybrid. The Perun kernel occupies the inner space only partially, and there is intermediate space between the kernel and the hull filled with spongy and elastic tissue. Those tissues are not a barrier to external force, so after the cracking of the hull, the stress is generated in the kernel. Such stress is not generated in the NS-H111 hybrid because the hollow inside of the seed is filled with the kernel, which produces some extra resistance to external force. The second important issue that affects the differences in compressive behavior of these two hybrids is the arrangement of pericarp tissues (Hernandez and Belles, 2007), which is characteristic of the genotype.

\section{CONCLUSION}

An examination of the physical properties of six domestic sunflower hybrids demonstrated that the highest values of length occurred for Pobednik (11.52 \pm 0.79 $\mathrm{mm})$, while Krajišnik had the lowest length values $(9.31 \pm 0.62 \mathrm{~mm})$. Bačvanin had the widest seed $(5.92 \pm 0.61 \mathrm{~mm})$, while the narrowest seed occurred in Šumadinac 
$(4.72 \pm 0.76 \mathrm{~mm})$. Pobednik $(4.87 \pm 0.55 \mathrm{~mm})$ had the thickest seed, while NS-H-1 11 $(2.90 \pm 0.43 \mathrm{~mm})$ had the thinnest seed. The highest value of seed sphericity occurred $(0.59 \pm 0.051)$ for the Bačvanin seed, while the lowest sphericity occurred for $(0.243 \pm 0.0461)$ Šumadinac. The highest values of bulk $\left(449.86 \pm 26.03 \mathrm{~kg} \mathrm{~m}^{-3}\right)$ and true densities $\left(701.21 \pm 31.42 \mathrm{~kg} \mathrm{~m}^{-3}\right)$ were measured for Pobednik seeds, while the lowest value $\left(330.10 \pm 10.41 \mathrm{~kg} \mathrm{~m}^{-3}\right.$ and $502.74 \pm 13.71 \mathrm{~kg} \mathrm{~m}^{-3}$, respectively) was observed for the Bačvanin hybrid. In the moisture range from $5 \%$ to $33 \%$ w.b., the hybrids Krajišnik, Šumadinac, Bačvanin and Pobednik had a decreasing trend of bio yield forces as the seed moisture content increased. The bio yield force for the NS-H-111 hybrid increased as a function of the moisture content; this hybrid displayed the highest bio yield force of $69.9 \mathrm{~N}$ at $31.7 \%$ w.b. of seed moisture. The relationship between seed deformation and moisture content is a linear increasing function for NS-H-111, Šumadinac, Krajišnik and Perun. The Bavčanin and Pobednik hybrids exhibit a maximum deformation of $2.32 \mathrm{~mm}$ at a moisture seed content of $12.8 \%$ w.b. and $2.43 \mathrm{~mm}$ at $13.5 \%$ w.b. of moisture, respectively. As the seed moisture contents increase beyond these values, the magnitude of deformation decreases. For hybrids NS-H-111, Šumadinac, Krajišnik and Perun, the increase of bio yield force work values occurs when the seed moisture content increases. The Bačvanin and Pobednik hybrids have a decreasing bio yield work tendency as a function of the seed moisture content. Šumadinac, Krajišnik, Bačvanin and Perun demonstrate a decreasing trend of bio yield modulus as the seed moisture content increases, while NS-H-111 and Pobednik do not follow this trend.

\section{ACKNOWLEDGEMENT}

This study was supported by grant No. TR-03105 of the Ministry of Science and Technological Development, Republic of Serbia.

\section{NOMENCLATURE}

$\begin{array}{ll}\text { L } & \text { Sample length, }(\mathrm{mm}) \\ \text { Dg } & \text { Geometric man diameter, }(\mathrm{mm}) \\ \text { Ey } & \text { Yield modulus of elasticity, }\left(\mathrm{N} \mathrm{mm}^{-1}\right) \\ \text { F } & \text { Bio yield force, }(\mathrm{N}) \\ \text { M } & \text { Mass, (g) } \\ \text { Mc } & \text { Moisture content on wet basis, (\% w.b.) } \\ \text { p } & \text { Porosity, (-) } \\ \text { S } & \text { Surface area, }\left(\mathrm{mm}^{2}\right) \\ \text { T } & \text { Thickness, }(\mathrm{mm}) \\ \text { W } & \text { Width, }(\mathrm{mm}) \\ \alpha & \text { Tilt angle, }(\mathrm{o}) \\ \delta \mathrm{H} & \text { Deformation, }(\mathrm{mm})\end{array}$




$\begin{array}{ll}\mu & \text { Static coefficient of friction, (-) } \\ \rho_{\mathrm{b}} & \text { Bulk density, }\left(\mathrm{kg} \mathrm{m}^{-3}\right) \\ \rho_{\mathrm{t}} & \text { True density, }\left(\mathrm{kg} \mathrm{m}^{-3}\right) \\ \Phi & \text { Sphericity, }\left(\mathrm{mm} \mathrm{mm}^{-1}\right)\end{array}$

\section{REFERENCES}

Babić, Lj. and Babić, M., 2001. The Influence of Drying on Conditional Secant Modulus of Elasticity for Soybean Kernel (in Serbian). J. Process. Energy Agric. 5: 3-6.

Babić, Lj. and Babić, M., 2011a. Drying and Storing (in Serbian). Faculty of Agriculture, University of Novi Sad, Academic Press, Novi Sad, Serbia. Pp. 306.

Babić, Lj., Babić, M., Turan, J., Kekić Matić, S., Radojčin, M., Mehandzić Stanisić, S., Pavkov, I. and Zoranović, M., 2011b. Physical and Stress-Strain Properties of Wheat (Triticum aestivum) Kernel. J. Sci. Food Agric. 91:1236-1243.

Coskun, M.B., Yalcin, I. and Ozarslan, C., 2006. Physical Properties of Sweet Corn Seed (Zea mays saccharata Sturt.). J. Food Eng. 74: 523-527.

Davis, R.M. and El-Okene, A.M., 2009. Mositure-Dependent Physical Properties of Soybean. Int. Agrophys. 23: 299-303.

Dursun, E. and Dursun, I., 2005. Some Physical Properties of Capar Seed. Biosystems Eng., 92: 237-245.

Gupta, R.K. and Das, S.K., 1997. Physical Properties of Sunflower Seeds. J. Agric. Eng. Res., 66: 1-8.

Gupta, R.K. and Das, S.K., 2000. Fracture Resistance of Sunflower Seed and Kernel to Compressive Loading. J. Food Eng. 46: 1-8.

Hernandez, L.F., and Belles, P.M., 2007. A 3-D Finite Element Analysis of the Sunflower (Helianthus annuus L.) Fruit. Biomechanical approach for the improvement of its hullability. J. Food Eng. 78: 861-869.

Ibar, H. and Ozoturk, T. 2008. Physical and Mechanical Properties of Soybean. Int. Agrophys., 22:239-244.

Isik, E. and Izli, N. 2007., Physical Properties of Sunflower Seeds (Helianthus annuus L.). Int. J. Agric. Res. 8: 677-686.

Jafari, S., Khazaei, J., Arabhosseini, A., Massah, J., Khostaghaya, M.H., 2011. Study on Mechanical Properties of Sunflower Seeds. EJPAU 14(1): 06.

Kaleemullah, S. and Gunasekar, J., 2002. Moisture Dependent Physical Properties of Arecanut Kernels. Biosystems Eng. 82: 331-338.

Karababa, E., 2006. Physical Properties of Popcorn Kernels. J. Food Eng. 72: 100-107.

Khodabakhshian, R., Emadi, B., Abbaspour Fard, M.H., 2010. Gravimetrical Properties of Sunflower Seeds and Kernels. World Appl. Sci. J. 8: 119-128.

Khodabakhshian, R., Emadi, B., Abbaspour Fard, M.H., Saiedirad, M.H., 2011. Modeling of Fracture Resistance of Sunflower Seed and its Kernel as a Function of Moisture Content, Variety, Size and Loading Orientation. Int. J. Food Eng. 7: DOI: 10.2201/1556-3758.21 18.

Konak, M., Carman, K., Aydin, C., 2002. Physical Properties of Chick Seeds. Biosystems Eng. 82: 73-78.

Maghsoudi, H., Khoshtaghaza, M.H., Minaei, S. and Dizaji Zaki, H., 2012. Fracture Resistance of Unsplt Pistachio (Pistacia vera L.) Nuts Against Splitting Force, Under Compressive Loading. J. Agr. Sci Tech. 14: 299-310.

Mohsenin, N.N., 1980. Physical Properties of Plants and Animal Materials. Gordon \& Breach Science Publisher, New York, USA. Pp. 742.

Oraki, H., Alahdadi, I., Parhizkar, F., 2011. Sunflower (Helianthus annuus L.L Hybrid Seeds Distribution Modelling: Normal, Lognormal and Weibull Models. Afr. J. Agric. Res. 6: 618-623.

Ozturk, T. and Esen, B., 2008. Physical and Mechanical Properties of Barley. Agric. Trop. Subtrop. 41: 117-121.

Regulations about agricultural crops quality, 1987. Republic of Serbia Directive (in Serbian). 47: 1165-1166.

Saiedirad, M.N., Tabatabaeefar, A., Mirsalehi, M., Badii, F., Varnamkhasti, M.G., 2008. Effects of Moisture Content, Seed Size, Loading Rate and Seed Orientation on Force and Energy 
Required for Fracturing Cumin Seed (Cuminum cyminum Linn.) Under Quasi-Static Loading. J. Food Eng. 86: 565-572.

Santalla, E.M. and Mascheroni, R.H., 2003. Physical Properties of High Oleic Sunflower Seeds. Food Sci. Tech. Int. 9: 435-442.

Seifi, M.R., 2010. Moisture-Dependent Physical Properties of Sunflower Seed (SHF8190). Mod. Appl. Sci. 4:135-143.

StatSoft, Inc., 2010. STATISTICA (data analysis software system), version 9. www.statsoft.com.

Taser, F.O., Altuntas, E., Ozgoz, E., 2005. Physical Properties of Hungarian and Common Vetch Seeds. J. Appl. Sci. 5: 323-326.

Una,1 H., Isik, E., Isli, N., Tekin, Y., 2008. Geometric and Mechanical Properties of Mung bean (Vigna radiata L.) Grain: Effect of Moisture. Int. J. Food Prop. 11:585-599.

Voća, S., Pliestić, S., Dobričević, N., Filipović, D., 2008. Physical and Mechanical Properties of Sunflower Seed (cv. Alexandra pr). Cereal. Res. Commun. 36: 471-474. 